\title{
Diagnostic Accuracy of Anthropometric Indicators in the Prediction of Urinary Incontinence in Physically Active Older Women
}

\section{Acurácia diagnóstica de indicadores antropométricos na predição de incontinência urinária em idosas fisicamente ativas}

\author{
Enaiane Cristina Menezes ${ }^{1}$ Janeisa Franck Virtuoso \\ Jodelle Machado Chagas ${ }^{1}$ Giovana Zarpellon Mazo ${ }^{1}$ \\ Post-Graduation Program in Sciences of Human Movement, \\ Universidade do Estado de Santa Catarina (Udesc), Florianópolis, \\ SC, Brazil \\ 2 Post-Graduation Program in Rehabilitation Sciences, Universidade \\ Federal de Santa Catarina (UFSC), Florianópolis, SC, Brazil
}

Eduardo Capeletto $^{1}$ Lislayne Luiza da Silva ${ }^{1}$

Address for correspondence Enaiane Cristina Menezes, MSc, Professor, Rua Pascoal Simone 358, Coqueiros, 88080-350Florianópolis, SC, Brasil (e-mail: enaianemenezes@gmail.com).
Rev Bras Ginecol Obstet 2016;38:399-404.

\begin{abstract}
Purpose To determine the diagnostic accuracy and the cutoff point of the variables conicity index, waist to height ratio and fat percentage to detect urinary incontinence in physically active older women.

Method A total of 152 women were analyzed. The instruments used were the International Physical Activity Questionnaire (IPAQ [Area 4]) to check the level of physical activity, and the Diagnostic Form to obtain sociodemographic data and presence of urinary incontinence. To calculate the conicity index, waist to height ratio and fat percentage, body mass, height and waist circumference were measured. Descriptive and inferential statistics were used. Cutoff points, sensitivity $(S)$ and specificity (SP) were determined by receiver operating characteristic (ROC) curves. A $5 \%$ significance level was adopted.

Results The prevalence of urinary incontinence was of $32.2 \%$. The cutoff point with better sensitivity and specificity for the conicity index was $1.23(\mathrm{~S}=87.8$; $\mathrm{SP}=35.9$ ); for the waist to height ratio, it was $0.57(S=79.6$; $S P=45.6)$; and for the fat percentage, it was $39.71(\mathrm{~S}=89.8$; $\mathrm{SP}=42.7)$. The area under the ROC curve was 0.666 for the conicity index, 0.653 for the waist to height ratio, and 0.660 for the fat percentage.

Keywords

- anthropometry

- ROC curve

- urinary incontinence

Conclusions The cutoff points for the anthropometric measurements conicity index, waist to height ratio and fat percentage indicate that these measures can be used to predict urinary incontinence in physically active older women. Furthermore, fat percentage seemed to be the best measure for this population.
\end{abstract}

received

February 24, 2016

accepted

July 12, 2016

published online

August 16, 2016
DOI http://dx.doi.org/

10.1055/s-0036-1592103. ISSN 0100-7203.
Copyright $@ 2016$ by Thieme Publicações License terms

Ltda, Rio de Janeiro, Brazil

(ㄷ) (i) $\ominus$ (5) 


\section{Resumo}

\author{
Palavras-chave \\ - antropometria \\ - curva ROC \\ - incontinência urinária
}

Objetivo Verificar a acurácia diagnóstica e o ponto de corte das variáveis índice de conicidade, razão cintura/estatura e percentual de gordura para detectar a incontinência urinária em idosas fisicamente ativas.

Métodos Foram avaliadas 152 idosas. Os instrumentos utilizados foram o Questionário Internacional de Atividade Física (IPAQ [Domínio 4]), para verificar o nível de atividade física, e a Ficha Diagnóstica, para obter dados sociodemográficos e da presença de incontinência urinária. Para os cálculos de índice de conicidade, razão cintura/estatura e percentual de gordura, mensuraram-se a massa corporal, estatura e perímetro da cintura. Utilizou-se estatística descritiva e inferencial. Os pontos de corte, sensibilidade (S) e especificidade (E) foram determinados por meio das curvas receiver operating characteristic (ROC). Adotou-se um nível de significância de 5\%.

Resultados A prevalência de incontinência urinária foi de $32,2 \%$. O ponto de corte com melhor sensibilidade e especificidade do índice de conicidade foi de 1,23 $(S=87,8 ; E=35,9)$, da razão cintura/estatura, de $0,57(S=79,6 ; E=45,6)$, e, para percentual de gordura, de $39,71(\mathrm{~S}=89,8 ; \mathrm{E}=42,7)$. A área sob a curva ROC foi de 0,666 para o índice de conicidade, 0,653 para a razão cintura/estatura, e 0,660 para o percentual de gordura.

Conclusões Os pontos de corte das medidas antropométricas índice de conicidade, razão cintura/estatura e percentual de gordura indicam que essas medidas podem ser utilizadas para predizer incontinência urinária em mulheres idosas fisicamente ativas. Além disso, o percentual de gordura demonstrou ser a melhor medida para esta população.

\section{Introduction}

Epidemiological studies have shown that obesity verified by the waist circumference (WC) and body mass index (BMI) is a risk factor for the presence of urinary incontinence (UI) and other pelvic floor disorders. ${ }^{1,2}$ A study ${ }^{3}$ followed women for a period of eight years and found that obesity is also associated with persistent UI, in which BMI $\geq 30 \mathrm{~kg} / \mathrm{m}^{2}$ increases by 4.12 times the risk of persistence of symptoms (odds ratio [OR] $=4.12$; $95 \%$ confidence interval $[95 \% \mathrm{CI}]=3.82-4.45)$.

It is believed that this occurs due to high body fat accumulation, especially in the abdominal area, which overloads the pelvic floor structures through increased intra-abdominal pressure $^{4}$ and lower activation of the pelvic muscles. ${ }^{5}$ However, although it is a risk factor well established in the literature, ${ }^{6,7}$ most studies evaluate overweight by BMI and WC. Other anthropometric measurements are still little explored, and also reflect the occurrence of overweight, such as conicity index (CI), waist to height ratio (WHtR) and fat percentage (FP). The use of the $\mathrm{CI}$ becomes relevant: since it is based on a probability model aimed to evaluate abdominal adiposity, the index takes into account the individual's weight and height. ${ }^{8}$ Specifically in the elderly, the WHtR has better predictive ability than BMI and $\mathrm{WC}^{9}{ }^{9}$ in addition, FP is an anthropometric indicator widely used in the literature. ${ }^{10,11}$

In addition to the need of understanding the predictive ability of other measures to UI in older women, it is emphasized that regular physical activity has been reported as a protective factor for UI in this population, ${ }^{12,13}$ which may favor another behavior pattern in the use of anthropometric measurements for UI.

Thus, it becomes important to understand the association between these measures and the presence of UI to determine the cutoffs that predict these symptoms in physically active older women. The aim of this study was to assess the diagnostic accuracy of the variables CI, WHtR and FP to detect UI and to determine the cutoff points for the anthropometric indicators that best predict this disease in physically active older women.

\section{Method}

\section{Study Type and Sample}

This is an analytical cross-sectional study, whose population consisted of 300 older women living in the city of Florianópolis, SC, Brazil, who participate in a physical activity program at a university. Data collection was performed from October to December 2010.

The sample was intentionally selected using the following inclusion criteria: woman aged 60 years or older, physically active, and with the absence of symptoms of urinary tract infection. To set the level of physical activity of the participants, the questions of the Area 4 of the International Physical Activity Questionnaire (IPAQ) were applied. They were related to physical activities of recreation, sports, exercise and leisure held in a normal week, with vigorous and/or moderate intensity for at least 10 minutes continuously. Those who reached 150 minutes per week or more were considered physically active. ${ }^{14,15}$ 
Based on these criteria, the sample consisted of 152 physically active older women.

\section{Instruments and Data Collection}

For this survey, the ethical principles in accordance with item IV of Resolution 466/2012 of the Brazilian National Health Council were met. The study was submitted to the Ethics Committee of Universidade do Estado de Santa Catarina (UDESC) and approved under protocol number 03/2010. The research was conducted in accordance with the Declaration of Helsinki (2008), and all participants signed the Informed Consent Form (ICF).

Data collection was performed by two trained researchers at a previously scheduled date, time and place. First, a diagnostic record containing information about the age, education, marital status and current occupation of the participants was collected through interviews.

The presence of UI was evaluated according to reports of symptoms of UI, defined by Haylen et $\mathrm{al}^{16}$ as "complaint of involuntary urine loss", through the following question: "During the last year, have you lost urine (unintentionally in panties) at least once a month?" When the answer was positive, it was characterized as presence of symptoms of UI. If negative, it was characterized as the absence of symptoms. To check the type of UI, the following questions were asked: "Do you lose urine when you cough, sneeze or carry weight?" If the answer was positive, it was considered effort urinary incontinence (EUI). "Do you lose urine before reaching the toilet after feeling a strong urge to urinate or without perceiving it?" If the answer was positive, it was considered urge urinary incontinence (UUI). When both symptoms were present, it was considered mixed urinary incontinence (MUI).

The anthropometric measurements collected were body weight, height and WC. Body mass was determined by means of a Plenna Wind MEA 07710 digital scale (São Paulo, Brazil), and height by a WCS $217 \mathrm{~cm}$ stadiometer with a CARDIOMED platform (Curitiba, Brazil). Body mass index was classified using the cutoff point proposed by the World Health Organization (WHO). ${ }^{17}$ The conicity index was calculated using weight, height, WC and the mathematical formula proposed by Valdez et al. ${ }^{8}$ For WC $(\mathrm{cm})$, the circumference relating to the midpoint between the last rib and the iliac crest was measured by means of a measure round tape with $1.50 \mathrm{~m}$ of ISP brand (Santa Teresa do Oeste, Brazil). ${ }^{18}$ The waist to height ratio was determined by dividing WC by stature. Fat percentage was calculated using the body density equation proposed by Tran and Weltman ${ }^{19}$ and Brozek et al. ${ }^{20}$

\section{Statistical Treatment}

Data were stored and analyzed using the Statistical Package for Social Sciences (SPSS, version 20.0, Armonk, USA). The numerical variables were presented as mean and standard deviation (SD), whereas categorical variables were expressed as relative frequency. To verify data distribution, the Kolmogorov-Smirnov test was used. Variable $\mathrm{Cl}$ did not show normal data distribution. To compare the anthropometric measurements ( $\mathrm{CI}, \mathrm{WHtR}$ and FP) and the presence of UI, the independent $t$-test or Mann-Whitney $U$ test was used, according to data distribution.

Cutoff points for anthropometric measurements were determined by the Receiver Operating Characteristic (ROC) curves. They identified the total area under the ROC curve and the cutoff points with better sensitivity and specificity for each measure. Values associated with the presence of UI and its subtypes were presented. The comparison between curves was performed in the MedCalc software demo version 3.1.1.1 (Ostend, Belgium). A 5\% significance level was adopted.

\section{Results}

Overall, 152 physically active older women with a mean age of 68.64 years $(S D=5.79$; minimum $=60$, maximum $=85$ ) were interviewed. As for sociodemographic characteristics, most of the sample had incomplete primary education (31.1\%), were married (52.6\%) and retired (55.0\%). Regarding BMI, 20.5\% had normal weight, 36.4\% were overweight, and 43.0\% were obese. Among women with UI, 12.2\% were classified as having a normal BMI, $30.6 \%$ as overweight, and $57.1 \%$ as obese.

The prevalence of UI was of $32.2 \%$. Symptoms of urinary loss during efforts was reported by $28.3 \%$, while urinary loss associated with the urge to urinate was $11.2 \%$. For $7.2 \%$ of the sample, both symptoms were present. As for anthropometric measurements, the average CI was $1.26(\mathrm{SD}=0.09)$, WHtR was $0.59(\mathrm{SD}=0.07)$, and FP was $41.72(\mathrm{SD}=5.61)$.

Regarding the comparisons of these anthropometric measurements, a significant difference between women with and without UI was observed, as well as between subtypes EUI and UUI. - Table 1 shows that the average values were higher among women with presence of these symptoms. The effect measure ( $d$ Cohen) pointed WHtR with a higher difference between continent and incontinent individuals.

Regarding the cutoff points of the $\mathrm{CI}$ (-Table $\mathbf{2}$ ), the area under the ROC curve was 0.666 . The cutoff point of 1.23 or more is the most suitable balance between sensitivity and specificity. In this cutoff point, the power of the CI to properly classify physically active older women with UI was high (87.8\% - sensitivity), while the power to correctly classify women without urinary incontinence was considered low (35.9\% - specificity).

With respect to WHtR and the presence of UI (-Table 2), we observed that the area under the ROC curve was 0.653. The cutoff point of 0.57 or more is the most suitable balance between sensitivity and specificity. In this cutoff point, the power of WHtR to properly classify physically active older women with UI was $79.6 \%$ (sensitivity), while the power of WHtR to correctly classify women without UI was $45.6 \%$ (specificity).

Regarding the cutoff points for FP, the area under the ROC curve was 0.660 . The cutoff point of 39.71 or more is the most suitable balance between sensitivity and specificity. In this cutoff point, the power of FP to correctly classify physically active older women with UI was high (89.8\% - sensitivity), 
Table 1 Comparison of the anthropometric measurements conicity index (CI), waist to height ratio (WHtR) and fat percentage (FP) among women with and without urinary incontinence (UI) and its subtypes $(n=152)$

\begin{tabular}{|c|c|c|c|c|c|c|}
\hline Variables & $\mathrm{Cl}^{\mathrm{A}}$ & SD & $W H t^{B}$ & SD & FP $(\%)^{B}$ & SD \\
\hline \multicolumn{7}{|l|}{ UI } \\
\hline $\begin{array}{l}\text { Yes }(n=49) \\
\text { No }(n=103)\end{array}$ & $\begin{array}{l}1.29 \\
1.25 \\
p=0.001^{*} \\
d=0.50\end{array}$ & $\begin{array}{l}0.07 \\
0.09\end{array}$ & $\begin{array}{l}0.62 \\
0.57 \\
p=0.001^{*} \\
d=0.77\end{array}$ & $\begin{array}{l}0.06 \\
0.07\end{array}$ & $\begin{array}{l}43.92 \\
40.67 \\
p=0.001^{*} \\
d=0.64\end{array}$ & $\begin{array}{l}4.32 \\
5.86\end{array}$ \\
\hline \multicolumn{7}{|l|}{ EUI } \\
\hline $\begin{array}{l}\text { Yes }(n=43) \\
\text { No }(n=109)\end{array}$ & $\begin{array}{l}1.29 \\
1.26 \\
p=0.044^{*} \\
d=0.40\end{array}$ & $\begin{array}{l}0.06 \\
0.09\end{array}$ & $\begin{array}{l}0.61 \\
0.58 \\
p=0.015^{*} \\
d=0.46\end{array}$ & $\begin{array}{l}0.06 \\
0.07\end{array}$ & $\begin{array}{l}43.62 \\
40.96 \\
p=0.008^{*} \\
d=0.52\end{array}$ & $\begin{array}{l}4.34 \\
5.89\end{array}$ \\
\hline \multicolumn{7}{|l|}{ UUI } \\
\hline $\begin{array}{l}\text { Yes }(n=17) \\
\text { No }(n=135)\end{array}$ & $\begin{array}{l}1.31 \\
1.26 \\
p=0.015^{*} \\
d=0.67\end{array}$ & $\begin{array}{l}0.06 \\
0.09\end{array}$ & $\begin{array}{l}0.63 \\
0.58 \\
p=0.018^{*} \\
d=0.77\end{array}$ & $\begin{array}{l}0.06 \\
0.07\end{array}$ & $\begin{array}{l}44.66 \\
41.35 \\
p=0.021^{*} \\
d=0.63\end{array}$ & $\begin{array}{l}4.96 \\
5.60\end{array}$ \\
\hline \multicolumn{7}{|l|}{ MUI } \\
\hline $\begin{array}{l}\text { Yes }(n=11) \\
\text { No }(n=141)\end{array}$ & $\begin{array}{l}1.28 \\
1.26 \\
p=0.633\end{array}$ & $\begin{array}{l}0.06 \\
0.09\end{array}$ & $\begin{array}{l}0.61 \\
0.59 \\
p=0.325\end{array}$ & $\begin{array}{l}0.06 \\
0.07\end{array}$ & $\begin{array}{l}43.89 \\
41.55 \\
p=0.18\end{array}$ & $\begin{array}{l}5.47 \\
5.61\end{array}$ \\
\hline
\end{tabular}

Abbreviations: $\mathrm{Cl}$, conicity index; $\mathrm{d}$, d Cohen; EUI, effort urinary incontinence; FP, fat percentage; $\mathrm{MUI}$, mixed urinary incontinence; $p$, significance level; SD, standard deviation; UI, urinary incontinence; UUI, urge urinary incontinence; WHtR, waist to height ratio.

${ }^{\text {A } M a n n-W h i t n e y ~ U}$ test;

Bindependent $t$-test.

Table 2 Area under the ROC curve, significance level ( $p$ ), cutoff points, sensitivity and specificity of the conicity index (CI), waist to height ratio (WHtR) and fat percentage (FP) as discriminators of the presence of urinary incontinence (UI) and its subtypes in physically active older women $(n=152)$

\begin{tabular}{|c|c|c|c|c|c|c|}
\hline Variables & Area under the ROC curve & $\begin{array}{l}95 \% \mathrm{Cl} \\
\text { Area under the ROC curve }\end{array}$ & $p$ & Cutoff point & Sensitivity & Specificity \\
\hline \multicolumn{7}{|l|}{ UI } \\
\hline $\mathrm{Cl}$ & 0.666 & $0.585-0.741$ & $<0.001$ & $>1.23$ & 87.8 & 35.9 \\
\hline WHtR & 0.653 & $0.572-0.729$ & 0.001 & $>0.57$ & 79.6 & 45.6 \\
\hline $\mathrm{FP}$ & 0.660 & $0.579-0.735$ & 0.001 & $>39.71$ & 89.8 & 42.7 \\
\hline \multicolumn{7}{|l|}{ EUI } \\
\hline $\mathrm{Cl}$ & 0.605 & $0.523-0.683$ & 0.044 & $>1.23$ & 86.0 & 33.9 \\
\hline WHtR & 0.604 & $0.521-0.682$ & 0.046 & $>0.55$ & 88.4 & 32.1 \\
\hline $\mathrm{FP}$ & 0.626 & $0.544-0.703$ & 0.015 & $>39.71$ & 88.4 & 40.4 \\
\hline \multicolumn{7}{|l|}{ UUI } \\
\hline $\mathrm{Cl}$ & 0.680 & $0.600-0.754$ & 0.016 & $>1.33$ & 41.2 & 88.9 \\
\hline WHtR & 0.678 & $0.598-0.752$ & 0.017 & $>0.63$ & 52.9 & 77.0 \\
\hline $\mathrm{FP}$ & 0.664 & $0.583-0.739$ & 0.029 & $>46.12$ & 47.1 & 80.0 \\
\hline \multicolumn{7}{|l|}{ MUI } \\
\hline $\mathrm{Cl}$ & 0.543 & $0.461-0.624$ & 0.640 & - & - & - \\
\hline WHtR & 0.578 & $0.496-0.658$ & 0.400 & - & - & - \\
\hline $\mathrm{FP}$ & 0.602 & $0.519-0.680$ & 0.276 & - & - & - \\
\hline
\end{tabular}

Abbreviations: $\mathrm{Cl}$, conicity index; EUI, effort urinary incontinence; FP, fat percentage; MUI, mixed urinary incontinence; $p$, significance level; ROC, receiver operating characteristic; UI, urinary incontinence; UUI, urge urinary incontinence; WHtR, waist to height ratio. 


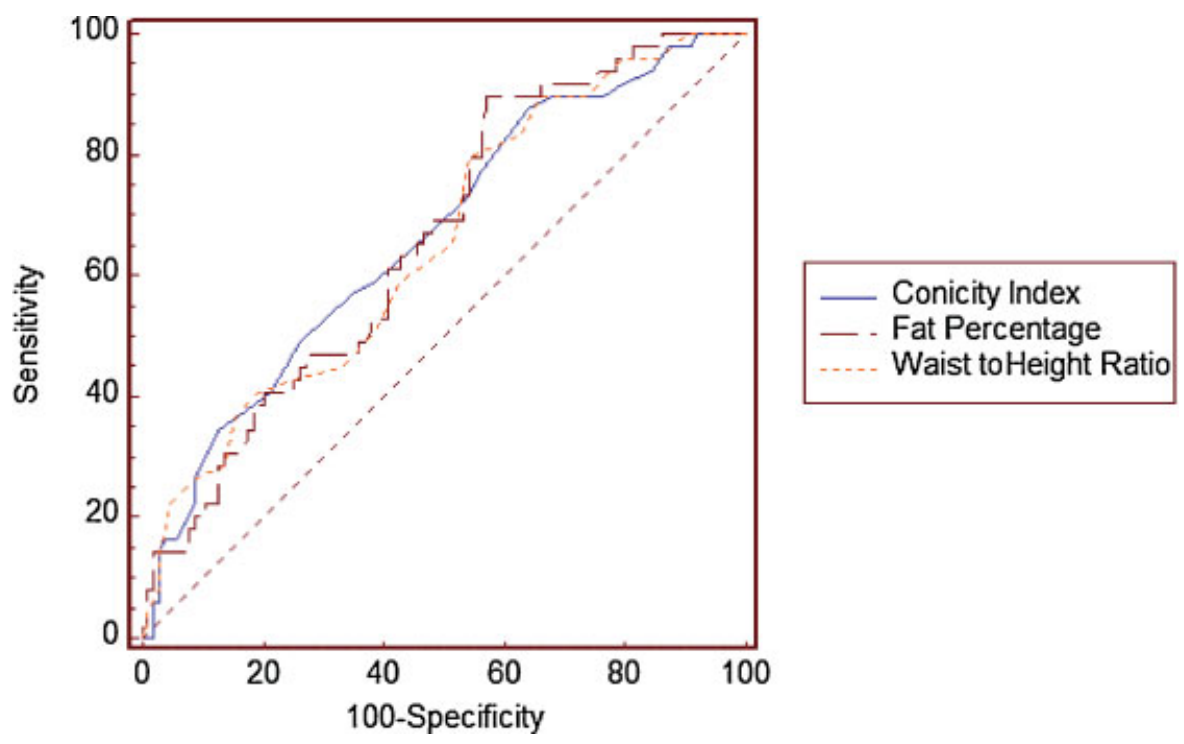

Fig. 1 Comparison between areas under the ROC curves for anthropometric measurements $(n=152)$.

while its power to correctly classify women without UI was considered low ( $42.7 \%$ - specificity). It is noteworthy that this measure had the best balance between specificity and sensitivity values for the study population.

The cutoff points and sensitivity and specificity values were similar when the presence of EUI and anthropometric measurements (-Table 2) was identified. The high prevalence of effort symptoms can explain this similarity. As for UUI, lower sensitivity values and higher specificity values were observed. It was not possible to identify a cutoff point for the presence of MUI.

- Fig. 1 shows a comparison between the areas of the ROC curves for $\mathrm{Cl}$, WHtR and FP associated with the occurrence of UI. This difference between areas was $0.013(p=0.745)$ for $\mathrm{CI}$ and WHtR, $0.006(p=0.902)$ for $\mathrm{CI}$ and FP, and 0.007 $(p=0.750)$ for WHtR and FP.

\section{Discussion}

We observed that physically active older women with UI had higher mean values for anthropometric measurements when compared with those without it. In addition, the cutoff points with the best balance between sensitivity and specificity for the $\mathrm{CI}$, WHtR and FP showed high sensitivity and low specificity values.

The low specificity value, which is the ability of the cutoff point to detect healthy individuals, can be explained by several factors. There is the possibility of not observing an optimal cutoff point in studies with a small sample size, which is an obstacle to estimate those values. ${ }^{21}$ Another factor that may explain the low specificity of cutoff points for anthropometric measurements is the regular practice of physical activity ${ }^{22}$ and increased abdominal fat during the aging process. ${ }^{23}$

When specifying cutoffs for anthropometric measurements to predict UI in older women, it should be taken into account that there is an increase in body fat, especially after menopause. This increase in body fat is well reported in the literature as a risk factor for UI in adults and older adults, ${ }^{3,7}$ which leads to a chronic increase in intra-abdominal pressure and symptoms of urinary loss. ${ }^{4}$ In addition, this increase in abdominal fat occurs during the aging process, which can be one of the factors that explain the low specificity values of the cutoff points established in this study.

Studies aimed at establishing cutoff points for anthropometric measurements to predict UI are scarce in the literature, especially in relation to older adults. However, a study by Sacomori et $\mathrm{al}^{24}$ proposed cutoff points for the adult population that were followed in the female cancer combat network of Florianópolis, SC, Brazil. We observed that, despite the fact that the characteristics of that sample are different from sample of the present study, the CI showed the same cutoff point (1.23; sensitivity 35.9 ; specificity 84.3 ), but with greater predictive ability to detect healthy subjects. The cutoff point established in the above-mentioned study for WHtR was 0.51 (sensitivity 59.0; specificity 63.7). This $6 \mathrm{~cm}$ difference when compared with the cutoff point given in this study may be explained by the physical changes during the aging process, ${ }^{23}$ in which there is loss of height ${ }^{25}$ and higher fat accumulation in the abdominal region. ${ }^{23}$

Furthermore, as mentioned above, changes in physical dimensions often verified by BMI and waist circumference (WC) are well reported in the literature as a risk factor for UI in older women. ${ }^{7,26}$ However, the difference in cutoff points used for the classification of individuals for use in analysis techniques hinders the comparison of results. Furthermore, the study found that in long-lived older women the WHtR showed better predictive ability of abdominal fat (sensitivity 97.5) compared with BMI and WC. ${ }^{9}$

Furthermore, in relation to the BMI and WC of physically active older women, the study found that these anthropometric measurements are not a risk factor associated with UI in this population. ${ }^{27}$ Another important factor is that the perceived aerobic capacity (able to run for 30 minutes) is associated with better muscle function of the pelvic floor $(\mathrm{OR}=1.63 ; 95 \% \mathrm{CI}$ 
1.27-2.09), ${ }^{28}$ which can reduce the association between these anthropometric variables and the presence of UI.

\section{Conclusion}

We observed that the anthropometric measurements WHtR, FP and CI are associated with the presence of UI. Cutoffs assigned to these measures to predict UI showed high sensitivity and low specificity for physically active older women.

Further studies should be conducted using more reliable measures to assess the body composition of the participants, as well as an urodynamic evaluation of UI. Nevertheless, the easy measurement of these measures and the high sensitivity of cutoff values to predict UI in physically active older women are emphasized. Due to their easy measurement, these measures can be included in the routine assessment of physically active older women by health professionals, thus contributing to preventive actions and UI diagnosis.

\section{References}

1 Subak LL, Wing R, West DS, et al; PRIDE Investigators. Weight loss to treat urinary incontinence in overweight and obese women. N Engl J Med 2009;360(5):481-490

2 Vaughan CP, Auvinen A, Cartwright R, et al. Impact of obesity on urinary storage symptoms: results from the FINNO study. J Urol 2013;189(4):1377-1382

3 Devore EE, Minassian VA, Grodstein F. Factors associated with persistent urinary incontinence. Am J Obstet Gynecol 2013; 209(2):145.e1-145.e6

4 Hunskaar S. A systematic review of overweight and obesity as risk factors and targets for clinical intervention for urinary incontinence in women. Neurourol Urodyn 2008;27(8):749-757

5 Talasz H, Himmer-Perschak G, Marth E, Fischer-Colbrie J, Hoefner E, Lechleitner M. Evaluation of pelvic floor muscle function in a random group of adult women in Austria. Int Urogynecol J Pelvic Floor Dysfunct 2008;19(1):131-135

6 Townsend MK, Danforth KN, Rosner B, Curhan GC, Resnick NM, Grodstein F. Body mass index, weight gain, and incident urinary incontinence in middle-aged women. Obstet Gynecol 2007;110 (2 Pt 1):346-353

7 Krause MP, Albert SM, Elsangedy HM, Krinski K, Goss FL, daSilva SG. Urinary incontinence and waist circumference in older women. Age Ageing 2010;39(1):69-73

8 Valdez R. A simple model-based index of abdominal adiposity. J Clin Epidemiol 1991;44(9):955-956

9 Santos VR, Christofaro DGD, Gomes IC, Santos LL, Freitas Júnior IF. Predictive capacity of anthropometric indicators for abdominal fat in the oldest old. Rev Bras Cineantropom Desempenho Hum. 2013;15(5):561-569

10 Gao HL, Gao HX, Sun FM, Zhang L. Effects of walking on body composition in perimenopausal and postmenopausal women: a systematic review and meta-analysis. Menopause 2016; [E-pub ahead of print]

11 Rech CR, Lima LRA, Cordeiro BA, Petroski EL, Vasconcelos FAG. Validade de equações antropométricas para a estimativa da gordura corporal em idosos do sul do Brasil. Rev Bras Cineantropom Desempenho Hum. 2010;12(1):1-7

12 Danforth KN, Shah AD, Townsend MK, et al. Physical activity and urinary incontinence among healthy, older women. Obstet Gynecol 2007;109(3):721-727

13 Lee AH, Hirayama F. Physical activity and urinary incontinence in older adults: a community-based study. Curr Aging Sci 2012;5(1): $35-40$

14 International Physical Activity Questionnaire (IPAQ) [Internet] Guidelines for data processing and analysis of the International Physical Activity Questionnaire (IPAQ): short and long forms. 2005 [cited 2015 Oct 12]. Available from: http://www.academia. edu/5346814/Guidelines_for_Data_Processing_and_AnalysiS_of_the_International_Physical_Activity_Questionnaire_IPAQ_Short_and_Long_Forms_Contents

15 Mazo GZ, Benedetti TRB. Adaptação do questionário internacional de atividade física para idosos. Rev Bras Cineantropom Desempenho Hum. 2010;12(6):480-484

16 Haylen BT, de Ridder D, Freeman RM, et al. An International Urogynecological Association (IUGA)/International Continence Society (ICS) joint report on the terminology for female pelvic floor dysfunction. Int Urogynecol J 2010;21(1):5-26

17 World Health Organization. Obesity: preventing and managing the global epidemic: report of a WHO consultation. Geneva: World Health Organization; 1998. (WHO Technical Report Series, 894)

18 Norton K, Whittingham N, Carter L, Kerr D, Gore C, Marfell-Jones M. Técnicas de medição em antropometria. In: Norton K, Olds T, editors. Antropométrica. Porto Alegre: Artmed; 2005.p. 41-87

19 Tran ZV, Weltman A. Generalized equation for predicting body density of women from girth measurements. Med Sci Sports Exerc 1989;21(1):101-104

20 Brozek J, Grande F, Anderson JT, Keys A. Densitometry analysis of body composition: revision of some quantitative assumptions. Ann N Y Acad Sci 1963;110:113-140

21 Martinez EZ, Louzada-Neto F, Pereira BB. A curva ROC para testes diagnósticos. Cad Saúde Coletiva. 2003;11(1):7-31

22 Bray GA, Frühbeck G, Ryan DH, Wilding JPH. Management of obesity. Lancet 2016;387(10031):1947-1956

23 Gravena AAF, Brischiliari SCR, Lopes TCR, Agnolo CMD, Carvalho MDB, Pelloso SM. Excess weight and abdominal obesity in postmenopausal Brazilian women: a population-based study. BMC Womens Health 2013;13:46

24 Sacomori C, Vinter CR, Sperandio FF, Pereira EF, Cardoso FL. Propuesta de puntos de corte para diferentes indicadores antropométricos en la predicción de la incontinencia urinaria en mujeres. Rev Chil Obstet Ginecol 2015;80(3):229-235

25 de Menezes TN, de Fátima Nunes Marucci M. Anthropometry of elderly people living in geriatric institutions, Brazil. Rev Saude Publica 2005;39(2):169-175

26 Moreno-Vecino B, Arija-Blázquez A, Pedrero-Chamizo R, et al; EXERNET Group. Associations between obesity, physical fitness, and urinary incontinence in non-institutionalized postmenopausal women: The elderly EXERNET multi-center study. Maturitas 2015;82(2):208-214

27 Virtuoso JF, Menezes EC, Mazo GZ. [Risk factors for urinary incontinence in elderly women practicing physical exercises]. Rev Bras Ginecol Obstet 2015;37(2):82-86. Portuguese

28 Sacomori C, Porto IP, Cardoso FL, Sperandio FF. Associação entre aptidão cardiorrespiratória percebida e função do assoalho pélvico em mulheres. Rev Bras Ciênc Esporte 2016; [E-pub ahead of print] 